\title{
Nutritional Counseling Promotes Changes in the Dietary Habits of Overweight and Obese Adolescents with Polycystic Ovary Syndrome
}

\section{$O$ aconselhamento nutricional promove mudanças nos hábitos alimentares de adolescentes com excesso de peso e obesas e com síndrome dos ovários policísticos}

\author{
Adriana Lúcia Carolo ${ }^{1}$ Maria Célia Mendes ${ }^{1}$ Ana Carolina Japur de Sá Rosa e Silva ${ }^{1}$ \\ Carolina Sales Vieira ${ }^{1}$ Marcos Felipe Silva de Sá ${ }^{1} \quad$ Rui Alberto Ferriani $^{1}$ Rosana Maria dos Reis ${ }^{1}$ \\ ${ }^{1}$ Faculdade de Medicina de Ribeirão Preto, Universidade de São Paulo, \\ Ribeirão Preto, SP, Brazil \\ Address for correspondence Rosana Maria dos Reis, Faculdade de \\ Medicina de Ribeirão Preto, Universidade de São Paulo, Av. \\ Bandeirantes, 3900, 14049-900, Ribeirão Preto, SP, Brazil \\ Rev Bras Ginecol Obstet 2017;39:692-696. \\ (e-mail: romareis@fmrp.usp.br).
}

\section{Abstract \\ Keywords \\ - obesity \\ - polycystic ovary syndrome \\ - adolescents \\ - weight loss \\ - nutritional guidance}

\section{Resumo}

Objective To evaluate the effects of nutritional counseling on the dietary habits and anthropometric parameters of overweight and obese adolescents with polycystic ovary syndrome (PCOS).

Methods This was a prospective, longitudinal and auto-controlled study. Thirty adolescents aged 13-19 years-old, diagnosed with PCOS received nutritional counseling and were followed-up for 6 months. After the follow-up period, the results were evaluated through body weight, body mass index (BMI) and waist circumference (WC). Results Sixty-percent of the adolescents adhered to the nutritional counseling and, of these, $50 \%$ lost weight. Adolescents who lost weight changed their dietary habits by adopting hypocaloric diets and eating more meals per day, as per nutritional counseling. The waist circumference (WC) decreased significantly, although the body weight decreased non-significantly after adoption of a hypocaloric diet.

Conclusion Although there was no significant weight loss, there was a considerable reduction in the WC associated with hypocaloric diets and with eating a greater number of meals per day.

Objetivo Avaliar os efeitos do aconselhamento nutricional sobre os hábitos alimentares e os parâmetros antropométricos de adolescentes com sobrepeso e obesidade e com síndrome do ovário policístico (SOP).

Métodos Este foi um estudo prospectivo, longitudinal e autocontrolado. Trinta adolescentes com idades entre 13 e 19 anos e diagnosticadas com SOP receberam aconselhamento nutricional. Após 6 meses de acompanhamento, os resultados foram avaliados através do peso corporal, índice de massa corporal (IMC) e a circunferência da cintura (CC). received

September 12, 2017 accepted

September 20, 2017

published online

October 30, 2017
DOI https://doi.org/

$10.1055 / \mathrm{s}-0037-1607458$. ISSN $0100-7203$.
Copyright $\odot 2017$ by Thieme Revinter

Publicações Ltda, Rio de Janeiro, Brazil
License terms

(c) $(1) \$$ 
Palavras-chave

- obesidade

- síndrome do ovário policístico

- adolescentes

- perda de peso

- orientação nutricional
Resultados Sessenta por cento das adolescentes aderiram ao aconselhamento nutricional e, destas, $50 \%$ perderam peso. Adolescentes que perderam peso mudaram seus hábitos alimentares adotando dietas hipocalóricas e comendo mais refeições por dia, seguindo orientação nutricional. A circunferência da cintura (CC) diminuiu significativamente, embora o peso corporal tenha diminuído de forma não significativa após a adoção de uma dieta hipocalórica.

Conclusão Embora a perda de peso não tenha sido significativa, houve redução considerável da CC associada a dietas hipocalóricas e à ingestão de um maior número de refeições por dia.

\section{Introduction}

Polycystic ovary syndrome (PCOS) is a common endocrine disorder among women of reproductive age, characterized by infertility, irregular menstruation, and clinical or biochemical signs of hyperandrogenism. ${ }^{1}$ The hormonal changes that occur in adolescents due to physiological hyperandrogenemia and hyperinsulinemia can be confounded with the PCOS, although they may be transient and stabilize later. ${ }^{2,3}$

Polycystic ovary syndrome is often associated with dyslipidemia and glucose intolerance, leading to increased incidence of type 2 diabetes, cardiovascular disease ${ }^{4}$ and endometrial hyperplasia. ${ }^{5}$ Women with PCOS have a greater risk of overweight, obesity, and central obesity. The prevention and management of overweight and obesity is recommended in the clinical management of PCOS. ${ }^{6}$ Data from the general Korean population showed an association between body weight changes and menstrual irregularity in obese women. Significant associations were only observed in women with obesity and abdominal obesity, evaluated by waist measurement, but not in non-obese or non-abdominally obese women. ${ }^{7}$

Lifestyle intervention is the first-line treatment in women with PCOS who are overweight or obese, and weight loss should be achieved through proper nutrition and physical exercise. ${ }^{8}$ Lifestyle changes have been shown to improve clinical and laboratory hyperandrogenism, insulin resistance and body composition. ${ }^{9}$ Recently, our group developed a progressive resistance training program to be performed 3 times a week for the period of 4 months. It showed that resistance exercise alone can improve hyperandrogenism, reproductive function, and body composition by decreasing visceral fat and increasing lean muscle mass; however, it had no metabolic impact on women with PCOS. ${ }^{10}$ This study aimed to evaluate the effects of nutritional counseling on the dietary habits and anthropometric parameters in overweight and obese adolescents with PCOS.

\section{Methods}

This is a prospective, longitudinal and auto-controlled pilot study that evaluated the effects of nutritional counseling on dietary habits, according to the recommendations of the food pyramid adapted to the Brazilian population, and anthropometric parameters of adolescents with PCOS. Nutritional follow-up lasted for 6 months.

Thirty adolescents aged 13-19 years were selected at the clinical hospital of Ribeirão Preto, Universidade de São Paulo, Brazil. The diagnosis of PCOS was based on the presence of oligomenorrhea and clinical and/or laboratory hyperandrogenism for over two years after menarche. ${ }^{11,12}$ The diagnosis of overweight and obesity was done according to the patient's body mass index (BMI) percentile (weight $/$ height ${ }^{2}\left[\mathrm{~kg} / \mathrm{m}^{2}\right]$ ). ${ }^{13}$

The study protocol was approved by the local Ethics Committee and all participants and legal representatives provided written informed consent.

A complete medical history, including dietary habits, was taken at baseline and a detailed physical examination was performed. Body weight, height, BMI, and waist circumference (WC) were determined before and after nutritional counseling. Adolescents were excluded from the study if they did not follow the nutritional guidelines or attended less than three scheduled appointments.

All participants received individualized nutritional guidance and were asked to change their current food intake and adopt a healthier eating habit to promote weight loss. A nutritional assessment of 40-50 minutes was performed once a month by the same nutritionist (Carolo, Adriana Lúcia) to ensure adherence to the dietary guidelines, manage weight control, and make possible changes to the dietary plan. The diet composition was quantified at baseline and after 6 months of follow-up using the AVANUTRI software (Avanutri, Três Rios, RJ, Brazil). A 24-hour recall survey was used to estimate nutrient intake prior to all visits. Participants were encouraged to perform regular physical activity.

The predictive equations for estimating basal metabolic rate (BMR) and activity factor (AF) were used to determine the calorie requirements of the participants. ${ }^{14}$ We adopted the ideal weight-for-age based on the BMI equation (IBW $\left.=\mathrm{h}^{2} \times 21\right) .{ }^{13}$

The macronutrient, carbohydrate, protein, and fat intake data from the 24-hour recall survey before and at the end of the study were converted into a percentage of the total energy intake (TEI) and classified as adequate, below or above the nutrient intake. A diet was considered adequate with: $55-75 \%$ of TEI from carbohydrates, $10-15 \%$ of TEI from protein and $15-30 \%$ of TEI from total fat. ${ }^{15}$ 
Table 1 Baseline anthropometric and biochemical parameters (mean $\pm \mathrm{SD}$ ) of adolescents with polycystic ovary syndrome (PCOS) in the weight loss (WL) and non-weight loss (NWL) groups

\begin{tabular}{|l|l|l|l|}
\hline Variable & WL $(\boldsymbol{n}=9)$ & NWL $(\boldsymbol{n}=9)$ & $p^{*}$ \\
\hline Age (years) & $16.56 \pm 1.33$ & $16.0 \pm 1.66$ & 0.09 \\
\hline Weight $(\mathrm{kg})$ & $88.1 \pm 13.28$ & $78.69 \pm 17.26$ & 0.18 \\
\hline BMI $\left(\mathrm{kg} / \mathrm{m}^{2}\right)$ & $32.7 \pm 4.66$ & $30.66 \pm 4.9$ & 0.63 \\
\hline WC $(\mathrm{cm})$ & $93.59 \pm 10.06$ & $98.44 \pm 16.02$ & 0.69 \\
\hline SBP $(\mathrm{mmHg})$ & $117.56 \pm 6.62$ & $117.78 \pm 6.67$ & 0.56 \\
\hline DBP (mmHg) & $76.67 \pm 5.1$ & $77.67 \pm 3.74$ & 0.95 \\
\hline $\begin{array}{l}\text { Insulin } \\
\text { (mg/dL) }\end{array}$ & $16.21 \pm 8.51$ & $17.96 \pm 13.41$ & 0.99 \\
\hline $\begin{array}{l}\text { Blood sugar } \\
(\mathrm{mg} / \mathrm{dL})\end{array}$ & $88.0 \pm 14.78$ & $79.33 \pm 12.56$ & 0.26 \\
\hline QUICKI & $0.32 \pm 0.02$ & $0.34 \pm 0.06$ & 0.99 \\
\hline $\begin{array}{l}\text { Total } \\
\text { cholesterol } \\
(\mathrm{mg} / \mathrm{dL})\end{array}$ & $168.33 \pm 32.69$ & $176.56 \pm 32.99$ & 0.47 \\
\hline $\begin{array}{l}\text { HDL-c } \\
(\mathrm{mg} / \mathrm{dL})\end{array}$ & $43.44 \pm 10.45$ & $39.44 \pm 10.09$ & 0.54 \\
\hline $\begin{array}{l}\text { LDL-c } \\
\text { (mg/dL) }\end{array}$ & $103.56 \pm 22.84$ & $105.0 \pm 28.61$ & 0.51 \\
\hline $\begin{array}{l}\text { Triglycerides } \\
(\mathrm{mg} / \mathrm{dL})\end{array}$ & $96.33 \pm 38.57$ & $160.22 \pm 67.8$ & 0.16 \\
\hline
\end{tabular}

Abbreviations: BMI, body mass index; DBP, diastolic blood pressure; QUICKI, Quantitative insulin sensitivity check index; SBP, systolic blood pressure; WC, waist circumference.

${ }^{*} p$-value: Kruskal-Wallis test.

The meal pattern of 3-4 meals per day was considered as standard and used for statistical purposes, and the meal pattern of 3 main meals with two small ones was considered as a goal. ${ }^{16}$

Total energy expenditure was calculated using the World Health Organization/Food and Agricultural Organization (WHO/FAO $)^{14}$ equations to determine the total caloric intake. Diets were considered normocaloric when the total intake was the same as predicted by the equations \pm a $10 \%$ margin of error and hypercaloric or hypocaloric when the intake was above or below the predicted values, respectively.

The data are presented as means \pm standard deviation (SD). All analyses were performed using the PROC FREQ procedure from the SAS 9.0 software (SAS Institute, Cary, NC, USA). ${ }^{17}$ The Fisher exact test ${ }^{18}$ was used to evaluate the relationship between the weight loss and the macronutrient intake and the number of meals per day. The McNemar test was used to compare the adequacy of macronutrient intake before and after nutritional guidance. ${ }^{19}$

\section{Results}

Thirty adolescents started the nutritional counseling program, but 12 did not adhere to the treatment and were excluded. Thus, 18 (60\%) girls were evaluated. After follow-up, the participants were grouped based on weight loss: nine (50\%) girls lost weight - weight loss group (WL), and nine (50\%) girls did not lose weight - non-weight loss group (NWL). The minimum and the average weight loss in the WL group was $5.0 \%$ and $6.7 \%$, respectively, whereas the average weight gain in the NWL group was $6.1 \%$. The anthropometric and biochemical parameters of the participants are shown in - Table 1 .

All adolescents in the WL group had hypocaloric diets at the last nutritional assessment, and in the NWL group, four had a hypocaloric diet, four had a hypercaloric diet, and one had a normocaloric diet. The intake of calories, carbohydrates, protein, and fat of the study is shown in - Table 2 . In the WL group, despite changes in the total macronutrient intake, macronutrient distribution remained within the recommended ranges. In the NWL group, no changes in the macronutrient distribution and no increase in the macronutrient intake were observed, but only an increase in the total food intake. No changes in the dietary intake habits were observed after nutritional counseling for some food groups, especially fruits, vegetables, and dairy products.

When evaluating the number of meals in the WL group at baseline, two girls (22.2\%) had the recommended intake, four (66.7\%) had the standard, and one $(11.1 \%)$ had less than three meals per day. At the end of the study, eight girls (88.9\%) had the recommended intake and one (11.1\%) had the standard number of meals. In the NWL group, at baseline, two girls (22.2\%) had the recommended number of portions, two (22.2\%) had the standard, and five (55.6\%) had fewer meals than recommended ( $p=0.14)$. At the end of the study, two girls (22.2\%) had the recommended intake, four (44.4\%) had the standard, and three (33.3\%) had less than three meals per day $(p=0.02)$. Breakfast was the most skipped meal of the day in the NWL group. There was a direct relationship between the number of meals per day and the weight loss in the WL group $(p=0.01)$.

Table 2 Baseline and final calorie, carbohydrate, protein and fat intake (mean \pm SD) in the weight loss (WL) and non-weight loss (NWL) groups

\begin{tabular}{|l|l|l|l|l|}
\hline \multirow{2}{*}{ Macronutrient } & \multicolumn{2}{|l|}{ WL $(\boldsymbol{n}=\mathbf{9})$} & \multicolumn{1}{l|}{ NWL $(\boldsymbol{n}=\mathbf{9})$} \\
\cline { 2 - 5 } & baseline & final & baseline & final \\
\hline Calories & $1,977.89 \pm 646.84^{\text {a }}$ & $1,520.89 \pm 219.58^{\text {a }}$ & $1,709.32 \pm 484.41$ & $2,128.71 \pm 617.24$ \\
\hline Carbohydrates & $60.01 \pm 11.37$ & $58.18 \pm 5.05$ & $57.55 \pm 13.6$ & $55.76 \pm 11.37$ \\
\hline Protein & $15.63 \pm 5.52$ & $19.01 \pm 4.15$ & $14.91 \pm 6.16$ & $15.35 \pm 3.7$ \\
\hline Fat & $24.37 \pm 9.46$ & $22.81 \pm 5.08$ & $27.53 \pm 10.0$ & $28.9 \pm 8.15$ \\
\hline
\end{tabular}

${ }^{a} p<0.01$ (Multiple linear regression analysis). 
Table 3 Anthropometric parameters (mean \pm SD) at baseline and after nutritional counseling in the weight loss (WL) and nonweight loss (NWL) groups

\begin{tabular}{|l|l|l|l|l|}
\hline \multirow{2}{*}{ Anthropometric parameters } & \multicolumn{2}{|l|}{ WL $(\boldsymbol{n}=9)$} & NWL $(\boldsymbol{n}=9)$ \\
\cline { 2 - 5 } & baseline & final & baseline & final \\
\hline Weight $(\mathrm{kg})$ & $88.1 \pm 13.3$ & $81.4 \pm 11.2$ & $78.7 \pm 17.3$ & $84.8 \pm 20.7$ \\
\hline BMI $\left(\mathrm{kg} / \mathrm{m}^{2}\right)$ & $32.7 \pm 4.67$ & $30.1 \pm 3.84$ & $30.6 \pm 4.9$ & $32.8 \pm 6.11$ \\
\hline WC $(\mathrm{cm})$ & $93.6 \pm 10.1^{\mathrm{a}}$ & $90.4 \pm 10.0^{\mathrm{a}}$ & $98.4 \pm 16.0$ & $102.4 \pm 22.4$ \\
\hline
\end{tabular}

Abbreviations: BMI, body mass index; WC, waist circumference.

${ }^{a} p<0.01$ (Multiple linear regression analysis).

The body weight, BMI, and WC before and after nutritional counseling for both study groups are shown in - Table 3. Six (66.7\%) adolescents in the WL group reported regular physical activity, mainly walking, during the dietary reeducation program.

\section{Discussion}

Thirty PCOS adolescents started the study, and 18 remained in the follow-up for 6 months. In the WL group, the total calorie intake decreased significantly, and $89.1 \%$ of the participants had the recommended number of meals. In the NWL group, the total calorie intake increased, although not significantly, and only $22.2 \%$ of the participants had the recommended number of meals. The consumption of fruits, vegetables, milk, and dairy products remained unchanged in the two groups, even after dietary guidance.

A strong limitation of this study was the very small number of volunteers who adhered to nutritional intervention. However, adherence of $60 \%$ to nutritional counseling in this study is considered adequate for this age group, and similar adherence rates have been reported. ${ }^{20,21}$

The waist circumference decreased in the WL group, even though the body weight and BMI decrease was not significant. Most adolescents in the WL group reported regular physical activity; however, physical activity was not monitored, which can also be considered a limitation of our study. Physical activity associated with nutritional counseling may contribute to the weight loss and WC reduction. ${ }^{22}$ In a randomized study with increased fiber and reduced trans fatty acid intake in overweight adult women with PCOS, the BMI, WC and total cholesterol were significantly reduced in the diet group as well as in the diet plus physical exercise group. However, in the group only with physical exercise, there was improvement only in body composition. ${ }^{23}$

We found a negative relationship between the calorie intake and the weight loss in the WL group, and adolescents showed a tendency to have a high-protein, low-carbohydrate/ fat diet. Similarly, a positive relationship between the weight loss and a high-protein, low-carbohydrate diet has already been reported. ${ }^{24}$

In the NWL group, only $44.4 \%$ of the participants had a hypocaloric diet at the end of the study. Participants in this group may have consumed low-calorie diets in an attempt to impose large caloric restrictions and achieve the desired weight faster. These caloric restrictions probably could not be followed for a long time, causing frustration and weight gain when participants reverted to their previous eating habits. Moreover, there is a high prevalence of therapeutic failures and recurrence of obesity in adolescents. ${ }^{25}$

Adolescents who lost weight had a tendency to consume a higher amount of protein than recommended, while consuming the recommended amounts of fat and carbohydrates. The consumption of hyperproteic diets increases the postprandial thermogenesis and has a greater satiety effect than highcarbohydrate, high-fat diets, which favors weight loss. It is very difficult to assess the efficacy of different weight-reducing diets. Thus, the total energy intake, satiety, hunger sensory triggers and palatability, rather than macronutrient distribution, should be considered when prescribing weight-reducing diets. ${ }^{26}$ The trend toward consumption of hyperproteic diets in our study may have been due to the selection of foods that provided greater satiety because high-protein diets were not specifically prescribed to participants. Nybacka et $\mathrm{al}^{23} \mathrm{dem}-$ onstrated that increased fiber intake was the strongest predictor of a reduced BMI, while decreased trans fatty acid intake predicted a reduced insulinogenic index.

Patients who presented a greater weight loss usually consumed more meals per day. Eating more frequent meals per day improves the control of the food intake and the feelings of satiety and hunger. In the NWL group, 33.3\% had fewer than three meals per day and breakfast was the most skipped meal of the day. In the investigation of the epidemiology of obesity in childhood and adolescence, the family environment (for example, obese parents), a sedentary lifestyle, and the consumption of high-calorie diets play a more significant role in the development of obesity than genetic factors. ${ }^{23}$

Our data showed that patients who presented greater weight loss exhibited body changes, especially a reduction in the WC. A recent review showed that a small reduction in weight, $\sim 5 \%$, can improve insulin resistance, reduce the levels of androgens and help with reproductive system dysfunctions in women. ${ }^{27,28}$ The BMI and the WC are predictors of cardiovascular risk factors in adults. ${ }^{29}$ However, there are few studies comparing the effects of both on cardiovascular risk factors, such as hypertension, in adolescents. In Korean adolescents, the BMI correlated more strongly with a high blood pressure than the WC. ${ }^{25,30}$ In a sample of Brazilian adolescents and adult women with PCOS, the BMI was an independent predictor of metabolic syndrome in adolescents. ${ }^{31}$ 


\section{Conclusion}

In conclusion, $60 \%$ of adolescents in this study adhered to nutritional counseling and, of these, $50 \%$ had a modest weight loss. Nutritional counseling promoted changes in the dietary habits of overweight and obese adolescents and, although there was not an important weight loss, there was a significant reduction in the WC associated with hypocaloric diets and with eating a greater number of meals per day.

\section{Conflicts to Interest}

Marcos Felipe Silva de Sá is an editor-in-chief at Revista Brasileira de Ginecologia e Obstetrícia and did not participate in the process of evaluation of the manuscript.

\section{References}

1 Moran LJ, Noakes M, Clifton PM, Tomlinson L, Galletly C, Norman RJ. Dietary composition in restoring reproductive and metabolic physiology in overweight women with polycystic ovary syndrome. J Clin Endocrinol Metab 2003;88(02):812-819. Doi: 10.1210/jc.2002020815

2 Goran MI, Gower BA. Longitudinal study on pubertal insulin resistance. Diabetes 2001;50(11):2444-2450. Doi: 10.2337/diabetes.50.11.2444

3 Joshi B, Mukherjee S, Patil A, Purandare A, Chauhan S, Vaidya R. A cross-sectional study of polycystic ovarian syndrome among adolescent and young girls in Mumbai, India. Indian J Endocrinol Metab 2014;18(03):317-324. Doi: 10.4103/2230-8210.131162

4 Norman RJ, Masters SC, Hague W, Beng C, Pannall P, Wang JX. Metabolic approaches to the subclassification of polycystic ovary syndrome. Fertil Steril 1995;63(02):329-335. Doi: 10.1016/ S0015-0282(16)57364-6

5 Kansra AR, Menon S. PCOS: perspectives from a pediatric endocrinologist and a pediatric gynecologist. Curr Probl Pediatr Adolesc Health Care 2013;43(05):104-113. Doi: 10.1016/j.cppeds.2013.01.002

6 Lim SS, Davies MJ, Norman RJ, Moran LJ. Overweight, obesity and central obesity in women with polycystic ovary syndrome: a systematic review and meta-analysis. Hum Reprod Update 2012; 18(06):618-637. Doi: 10.1093/humupd/dms030

7 Ko KM, Han K, Chung YJ, Yoon KH, Park YG, Lee SH. Association between body weight changes and menstrual irregularity: the Korea National Health and Nutrition Examination Survey 2010 to 2012. Endocrinol Metab (Seoul) 2017;32(02):248-256. Doi: 10.3803/EnM.2017.32.2.248

8 Fauser BC, Tarlatizis BC, Rebar RW, et al. Consensus on women's health aspects of polycystic ovary syndrome (PCOS); The Amsterdam SHRE/ASRM - Sponsored 3rd PCOS consenus workshop group. Fertil Steve 2012;27(01):28-38

9 Moran LJ, Hutchison SK, Norman RJ, Teede HJ. Lifestyle changes in women with polycystic ovary syndrome. Cochrane Database Syst Rev 2011;(07):CD007506. Doi: 10.1002/14651858.CD007506.pub3

10 Kogure GS, Miranda-Furtado CL, Silva RC, et al. Resistance exercise impacts lean muscle mass in women with polycystic ovary syndrome. Med Sci Sports Exerc 2016;48(04):589-598. Doi: 10.1249/MSS.0000000000000822

11 Azziz R, Carmina E, Dewailly D, et al; Androgen Excess Society. Positions statement: criteria for defining polycystic ovary syndrome as a predominantly hyperandrogenic syndrome: an Androgen Excess Society guideline. J Clin Endocrinol Metab 2006;91 (11):4237-4245. Doi: 10.1210/jc.2006-0178

12 Legro RS, Arslanian SA, Ehrmann DA, et al; Endocrine Society. Diagnosis and treatment of polycystic ovary syndrome: an Endocrine Society clinical practice guideline. J Clin Endocrinol Metab 2013;98 (12):4565-4592. Doi: 10.1210/jc.2013-2350
13 Quételet A. Antropométrie ou mesure des différentes facultés de l'homme.. Bruxelles: C. Muquardt; 1870

14 Food and Agriculture Organization. World Health Organization. United Nations. Energy and protein requirements. Geneva: WHO; 1985. (WHO Technical report series; 724)

15 World Health Organization. Diet, nutrition and prevention of chronic diseases: Report of a Joint WHO/FAO Expert Consultation. Geneva: WHO; 2003. (WHO Technical Report Series; 916)

16 Lichtenstein AH, Appel LJ, Brands M, et al; American Heart Association Nutrition Committee. Diet and lifestyle recommendations revision 2006: a scientific statement from the American Heart Association Nutrition Committee. Circulation 2006;114(01):82-96

17 SAS Institute Inc. SAS/STAT® User's Guide. Version 9.0. Cary: SAS Institute; 1999

18 Pagano M, Gauvreau K. Princípios de bioestatística.. São Paulo: Thomson; 2004

19 Conover WJ. Practical nonparametric statistics.. New York: John Wiley \& Sons; 1981

20 Almeida JC, Rodrigues TC, Silva FM, Azevedo MJ. Systematic review of weight loss diets: role of dietary components. Arq Bras Endocrinol Metabol 2009;53(05):673-687. Doi: 10.1590/ S0004-27302009000500020

21 Palomba S, Giallauria F, Falbo A, et al. Structured exercise training programme versus hypocaloric hyperproteic diet in obese polycystic ovary syndrome patients with anovulatory infertility: a 24-week pilot study. Hum Reprod 2008;23(03):642-650. Doi: 10.1093/humrep/dem391

22 Leite N, Milano GE, Cieslak F, Lopes WA, Rodacki A, Radominski RB. Effects of physical exercise and nutritional guidance on metabolic syndrome in obese adolescents. Rev Bras Fisioter 2009;13:73-81. Doi: 10.1590/S1413-35552009005000009

23 Nybacka Å, Hellström PM, Hirschberg AL. Increased fibre and reduced trans fatty acid intake are primary predictors of metabolic improvement in overweight polycystic ovary syndromeSubstudy of randomized trial between diet, exercise and diet plus exercise for weight control. Clin Endocrinol (Oxf) 2017; *..;. Doi: $10.1111 /$ cen. 13427

24 Krebs NF, Gao D, Gralla J, Collins JS, Johnson SL. Efficacy and safety of a high protein, low carbohydrate diet for weight loss in severely obese adolescents. J Pediatr 2010;157(02):252-258. Doi: 10.1016/j. jpeds.2010.02.010

25 Escrivão MA, Oliveira FL, Taddei JA, Lopez FA. [Childhood and adolescent obesity]. J Pediatr (Rio J) 2000;76(Suppl 3):S305-S310

26 Foreyt JP, Salas-Salvado J, Caballero B, et al. Weight-reducing diets: are there any differences? Nutr Rev 2009;67(Suppl 1): S99-S101. Doi: 10.1111/j.1753-4887.2009.00169.x

27 Silveira D, Taddei JA, Escrivão MA, Oliveira FL, Ancona-Lopez F. Risk factors for overweight among Brazilian adolescents of low-income families: a case-control study. Public Health Nutr 2006;9(04):421-428

28 Faghfoori Z, Fazelian S, Shadnoush M, Goodarzi R. Nutritional management in women with polycystic ovary syndrome: A review study. Diabetes Metab Syndr 2017;•••:S1871-4021(17) 30011-5. Doi: 10.1016/j.dsx.2017.03.030

29 Mohammadifard N, Nazem M, Sarrafzadegan N, et al. Body mass index, waist-circumference and cardiovascular disease risk factors in Iranian adults: Isfahan healthy heart program. J Health Popul Nutr 2013;31(03):388-397. Doi: 10.3329/jhpn.v31i3.16831

30 Song YH. The association of blood pressure with body mass index and waist circumference in normal weight and overweight adolescents. Korean J Pediatr 2014;57(02):79-84. Doi: 10.3345/ kjp.2014.57.2.79

31 Pedroso DCC, Melo AS, Carolo AL, Vieira CS, Rosa e Silva ACJS, dos Reis RM. [Frequency and risk factors for metabolic syndrome in adolescents and adults women with polycystic ovary syndrome]. Rev Bras Ginecol Obstet 2012;34(08):357-361. Doi: 10.1590/ S0100-72032012000800003 